ISSN 1392-3196 / e-ISSN 2335-8947

Zemdirbyste-Agriculture, vol. 105, No. 1 (2018), p. 21-26

DOI $10.13080 /$ z-a.2018.105.003

\title{
Weed density in the spring rape crops sown at different dates
}

\author{
Rimantas VELIČKA, Rita PUPALIENĖ, Lina Marija BUTKEVIČIENĖ, \\ Robertas KOSTECKAS, Zita KRIAUČIŪNIENĖ, Silvija KOSTECKIENĖ
}

Aleksandras Stulginskis University

Studentų 11, Akademija, Kaunas distr., Lithuania

E-mail: silvija.kosteckiene@asu.lt

\begin{abstract}
The climate warming and earlier beginning of the vegetation period have enabled earlier sowing of agricultural crops. Sowing date can affect weed density in crops, including spring oilseed rape. Field experiments were carried out in 2015 and 2016 at the Experimental Station of Aleksandras Stulginskis University. The soil of the experimental site is Calc(ar)i-Endohypogleyic Luvisol $(L V g-n-w-c c)$. The aim of the investigation was to evaluate the response of weed density in spring oilseed crop to the sowing date. In 2015, the first sowing date was 15 April. Afterwards the sowing was performed every 5 days until 20 May. In 2016, the first sowing date was 10 April. Afterwards the sowing was performed every 5 days until 25 May (except for the $7^{\text {th }}$ and $8^{\text {th }}$ sowing date, the interval between which was 10 days because of the adverse weather conditions). The number of weed seedlings and the number of weeds before harvesting differed between the experimental years. In 2015, with a delay in spring oilseed sowing until 5 May, the number of weed seedlings decreased. The highest number of weed seedlings was recorded in the plots sown on 10 May, and later it declined. In 2016, a 10-15 day delay in sowing resulted in significantly the highest number of emerged weeds, and in the plots sown at later dates the number of weeds inconsistently decreased. In 2015, with a delay in spring oilseed rape sowing until 20 May, the number of weeds before harvesting had decreased by $67.8 \%$. In the crops sown on 30 April and at later dates, the dry mass of weeds before harvesting increased from 2.7 to 27.1 times in the crop sown at the last sowing date and had significant effect on rapeseed yield. In 2016, significantly the lowest number and dry mass of weeds were established in the crops sown at the earliest dates (10 and 15 April) and in those sown at the latest dates (10, 20 and 25 May). In 2015, a statistically significant relationship was established between the dry matter mass of weeds and rapeseed yield $(r=-0.84, P<$ 0.001 ). A statistically significant correlation was also determined between the length of the period from oilseed rape sowing to complete maturity and dry matter mass of weeds $(r=-0.89, P<0.01)$. In 2016, no statistically significant correlations were found between the weed incidence in the spring oilseed rape crop and rapeseed yield.
\end{abstract}

Key words: sowing date, spring oilseed rape, weeds.

\section{Introduction}

The amount of the primary production, derived through plant photosynthesis in agriculture, in other words crop productivity, depends on the geographical location, soil, intensity of agronomic practices employed and agro-climatic conditions (Čiuberkis et al., 2010). The efficiency and competitiveness of agricultural production is heavily reliant on the climate, which is changing faster than predicted. Climate change remains one of the major problems of the $21^{\text {st }}$ century. Further emissions of greenhouse gases cause climate warming and long-term changes in all elements of the climate system as well as increase the likelihood of irreversible consequences for humans and ecosystems (Reidsma et al., 2010; IPCC, 2013). The challenge of adapting the agricultural sector to climate change encompasses not only crop productivity enhancement but also conservation of soil and water resources (Olesen et al., 2011). Climate change in Lithuania manifests itself by a rapid increase in air temperature and precipitation in the winter and a more consistent rise in temperature and decreasing rainfall in the summer (Kažys et al., 2011). According to Stuogè et al. (2011), in Lithuania, the agricultural sector will be most affected by early spring and autumn frosts, heat waves and squalls. With increasing average annual and July temperatures, droughts will occur, and excess moisture will favour the influx of pests, diseases and weeds in agricultural crops. Radzevičius (2011) has reported that droughts occurring during the growing season are likely to decrease crop yields by $51-75 \%$, while heavy rainfalls, winds and resulting soil degradation - by up to $25 \%$.

Rapeseed yields are decreasing not only due to the spread of pests; weeds can also have a considerable impact on yield losses (Peltonen-Sainio et al., 2009). Oerke (2005) has pointed out that the heaviest crop

Please use the following format when citing the article:

Velička R., Pupalienė R., Butkevičienė L. M., Kosteckas R., Kriaučiūnienė Z., Kosteckienė S. 2018. Weed density in the spring rape crops sown at different dates. Zemdirbyste-Agriculture, 105 (1): 21-26 DOI 10.13080/z-a.2018.105.003 
yield losses in agriculture are incurred due to high weed incidence in crops, yield losses to weeds account for about $34 \%$, while those resulting from pests and diseases are lower and account for about 16-18\%.

Growing together with cultivated plants, weeds reduce their productivity and deteriorate the quality of production. Weeds deprive crop plants of moisture and nutrients, block the light and thus deprive them of warmth. Compared to cultivated crops, weeds are better adapted to soil and climate conditions, they can better withstand nutrient shortage and survive during a droughty period. They are known to evaporate more moisture than cultivated plants (Čiuberkis, Vilkonis, 2013).

In Lithuania, spring oilseed rape is usually sown as early as possible, when the soil has reached physical maturity, i.e. a condition which allows tillage. However, spring frosts, summer heat and droughts markedly affect the development, yield formation processes of agricultural crops, and consequently reduce their economic productivity. The main reason why it is necessary to improve and adapt spring oilseed rape cultivation technology is the changing climate (colder and longer-lasting spring, increased leaching of nutrients from the soil during the autumn and winter periods). Presently, many farmers sow spring oilseed rape either too early or too late, which causes significant yield losses. Optimal sowing timing would ensure more efficient application of plant protection and weed control products, and consequently would create better conditions for rapeseed yield formation. The crop-weed competition shows the negative relationships among plants that arise when the needs of all growing plants cannot be met due to the lack of resources. As long as the conditions are optimal, the competition does not occur between the plants of the same species or those of different species. Weeds smother rape plants particularly strongly at the beginning of the growing season and in thinned out crops (Bilsborrow et al., 1993). Marcinkevičienè et al. (2010) suggest that the ability of spring oilseed rape to smother weeds is determined by an increase in crop biomass and a decrease in light flow on the soil surface. Bullied et al. (2006) have found that the earlier the rape crop is sown and the denser the stand is formed, the higher the competitive power of the crop is.

Romaneckienè et al. (2008) have documented that in May and June the germination of weeds reaches its peak when the soil temperature ranges between 10 $15^{\circ} \mathrm{C}$, later it gradually decreases, and in the summer, after more abundant rainfall, weed germination does not reach the spring level.

Weeds cannot be controlled by choosing a single technology, since there is no universal method for controlling them. The best control has proved to be the one that combines several methods (Riemens et al., 2007). At present, special attention is paid to integrated weed management, which combines biological, physical and chemical methods, in order to ensure a long-term crop protection and to reduce environmental impacts (Deytieux et al., 2012). For designing innovative weed management strategies simulation models can be useful (Parsons et al., 2009; Colbach et al., 2014; Renton, Chauhan, 2017).

The aim of this investigation was to evaluate the response of weed density in spring oilseed crop to the sowing date. Weed density in spring rape crop can be significantly affected by a sowing date.

\section{Materials and methods}

Field experiments on spring oilseed rape sowing dates were carried out in 2015 and 2016 at Aleksandras Stulginskis University's Experimental Station. The soil of the experimental site is Calc(ar)i-Endohypogleyic Luvisol (LVg-n-w-cc) (WRB, 2014). The agrochemical characteristics of the experimental soil are as follows (the data averaged over 2015 and 2016): $\mathrm{pH}-7.10$, humus content $-1.85 \%$, content of available nutrients in the soil: $\mathrm{P}_{2} \mathrm{O}_{5}-234 \mathrm{mg} \mathrm{kg}^{-1}, \mathrm{~K}_{2} \mathrm{O}-106 \mathrm{mg} \mathrm{kg}^{-1}$. Sowing timing of spring oilseed rape was investigated at Aleksandras Stulginskis University's Experimental Station during the period 2015-2016.

The experiment involved a spring oilseed rape (Brassica napus L) cultivar 'Fenja' (WvB, Germany), which was sown at a rate of $4 \mathrm{~kg} \mathrm{ha}^{-1}$ by a Multidrill M-300 (RabeWerk, Germany). The experiments included four replications. The first sowing date was when the soil had reached physical maturity. In 2015, the first sowing date was 15 April. Afterwards the sowing was performed every 5 days until 20 May. In 2016, the first sowing date was 10 April. Afterwards the sowing was performed every 5 days until 25 May (except for the $7^{\text {th }}$ and $8^{\text {th }}$ sowing date, the interval between which was 10 days because of the adverse weather conditions). The pre-crop of spring oilseed rape was winter wheat. Soil tillage in the experiment was carried out in accordance with the conventional technology of spring rape cultivation. In 2015 and 2016, prior to sowing, the total experimental area was fertilized with NPK 15-15-15 $360 \mathrm{~kg} \mathrm{ha}^{-1}$. Ammonium nitrate at a rate of $200 \mathrm{~kg} \mathrm{ha}^{-1}$ was applied on the total experimental area at a spring oilseed rape bud formation stage. The following plant protection products were used in the field experiment: in each treatment shortly after sowing (within one hour) herbicide Sultan super $21 \mathrm{ha}^{-1}$, insecticides were used during the growing season according to the need, fungicides were not used.

Assessment of weed incidence. The analysis of weed seedlings was first performed at the 3-4 leaf stage (BBCH 13-14). The number of weed seedlings was determined in each plot in 5 randomly selected 0.1 $\mathrm{m}^{-2}$ plots. Another assessment of weed incidence was performed at the end of spring rape growing season (BBCH 79) before harvesting in each plot in 5 randomly selected $0.1 \mathrm{~m}^{-2}$ plots. The weeds were uprooted from the plots and wrapped in paper. The weeds were analysed in a laboratory by dividing them into species, the weeds of each species were counted and wrapped again in paper and dried in a drying chamber. Dried weeds of each species were weighed. The number of weeds was recalculated in weeds $\mathrm{m}^{-2}$ and dry mass in $\mathrm{g} \mathrm{m}^{-2}$. In the experiment, the weed incidence data which did not meet the law of normal distribution, were transformed before statistical evaluation using the function $y=\log (x+1)$. The research data were statistically processed by the technique of one-way analysis of variance of quantitative attributes, and by correlation and regression methods. Statistical analysis of the experimental data was done using the software $A N O V A$ and STAT form the programme package SELEKCIJA (Raudonius, 2017). Significance of differences was estimated using the Duncan criterion. Significant differences were determined at $95 \%$ probability level. $P>0.05$ denotes no significant differences.

Meteorological conditions. In 2015, April was by $1^{\circ} \mathrm{C}$ warmer than usual and the total amount of the monthly precipitation was by $8 \mathrm{~mm}$ higher than the long- 
term average and was favourable for spring oilseed rape emergence. The air temperature of May was by $0.9^{\circ} \mathrm{C}$ lower and the monthly amount of rainfall by $10 \mathrm{~mm}$ lower than the long-term average, and this was one of the reasons for a significant reduction in crop germination. The average air temperature of June and July was close to the long-term average, while there was a shortage of rainfall: in June it was by $46 \mathrm{~mm}$, in July by $9 \mathrm{~mm}$ lower than the long-term average. In August, the monthly air temperature exceeded the long-term average by $4.0^{\circ} \mathrm{C}$, and the amount of rainfall was by $73.4 \mathrm{~mm}$ lower than usual.

In 2016, the spring was early. The average air temperature of March was by $1.8^{\circ} \mathrm{C}$ higher than the long-term average and the amount of precipitation by 10 $\mathrm{mm}$ higher compared with the long-term average. The conditions were favourable for planning an early sowing campaign of spring oilseed rape.

April was warm and wet. During the oilseed rape sowing period (10-30 April) the average daily air temperature was by $7.4^{\circ} \mathrm{C}$ higher and the amount of precipitation by $20.1 \mathrm{~mm}$ higher than the long-term average. The heavy rainfall that started within the first tenday period of April and the resulting excess of moisture had adverse effect on the emergence of weeds and spring oilseed rape. The average daily air temperature of May was by $2.5^{\circ} \mathrm{C}$ higher than the long-term average and the amount of rainfall was by $25.3 \mathrm{~mm}$ lower than the longterm average. The shortage of moisture is likely to have negatively affected the initial growth stages of the earlysown (05-25 April) oilseed rape despite the fact that the soil had accumulated considerable moisture reserves. In 2016 , the beginning of the summer was warm and wet. The average daily temperature of June exceeded the longterm average by $1.1^{\circ} \mathrm{C}$ and the amount of rainfall exceeded the long-term average by $7 \mathrm{~mm}$. The weather conditions were favourable for the growth of spring oilseed rape.

The average daily temperature of July was slightly lower (by $0.8^{\circ} \mathrm{C}$ ) than the long-term average and the amount of rainfall was by 66.3 higher $\mathrm{mm}$ higher than the long-term average. Moisture excess was felt during the seed formation period, which favoured the occurrence of diseases. The average daily air temperature of August was by $0.4^{\circ} \mathrm{C}$ higher than the long-term average, and the excess of rainfall (by $26 \mathrm{~mm}$ higher than the long-term average) interfered with harvesting operations.

\section{Results and discussion}

Weed counts in spring oilseed rape crops in 2015 and 2016. Seem et al. (2003) have documented that the crop ability to suppress weeds is strongly influenced by the weather conditions of a specific period, the dominant weed species and weed infestation severity. Sowing time, crop stand density and pre-crop also exert significant influence on the competitive power of a crop (Bullied et al., 2006; Valantin-Morison, Meynard, 2008; Velička et al., 2015).

In 2015 , the highest weed count $44.0 \mathrm{~m}^{-2}$ was recorded in the spring oilseed rape crop sown on a later date 10 May (Fig. 1). However, significant difference in weed counts (3.0-9.2 times lower) was found in the crops sown on 25 and 30 April, and in May - in the crops sown on 5 and 20 May compared with the highest weed number in oilseed rape crop sown on 10 May. After oilseed rape sowing at the beginning of May (on 5 May), heavy rainfall occurred $(21 \mathrm{~mm}$, nearly half of the total monthly rainfall), which had significant effect on the emergence of both oilseed rape plants and weeds. The crop sown on May 10 had enough moisture and warmth for emergence and establishment but weeds were better at taking advantage of the favourable conditions. For the crops sown at the latest dates (15 and 20 May), weed seedlings were killed by pre-sowing soil cultivation. The small amount of rainfall in the third ten-day period of May was also a contributing factor.

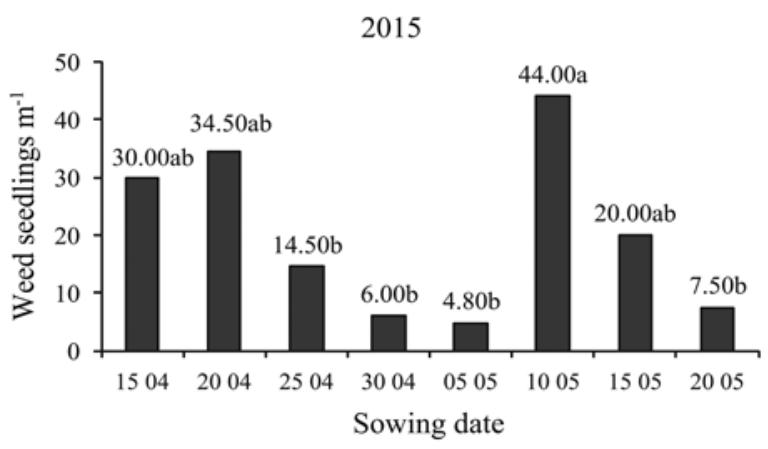

2016

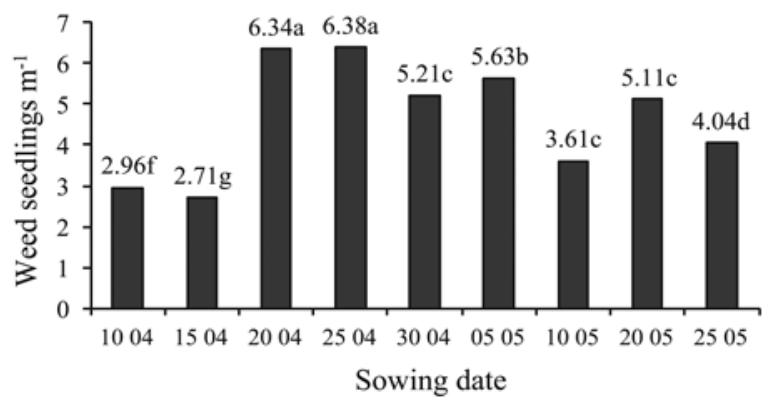

Note. Means followed by different letters $(a, b, \ldots)$ differ from each other significantly.

Figure 1. The number of weed seedlings in spring oilseed rape crop in 2015 and 2016

The weed counts in the spring oilseed rape crops sown at different dates in 2016 were lower compared with those recorded in 2015 . The weed counts significantly differed in spring oilseed rape crops sown at different dates. The low precipitation and cool weather during the first ten-day period of April inhibited weed germination. As a result, the number of weed seedlings in early-sown (10 and 15 April) spring oilseed rape crops was significantly, by approximately $45.3 \%$, lower compared with the crops sown at later dates (Fig. 1). With increasing rainfall and average daily temperature, the emergence of weeds became more intensive. The highest counts of weeds were determined in the crops sown on 20 and 25 April, they were by on average $52.1 \%$ higher than in the crops sown before or after these dates. With a 20-day delay in sowing, the number of weed seedlings decreased; however, compared with the crops of an early sowing date, it remained significantly higher. With a further delay in sowing (in May) the number of weed seedlings varied inconsistently but significantly.

In 2015 and 2016, there was found no statistically significant correlation between the number of weed seedlings in the crop and weed counts before oilseed rape harvesting. No statistically significant correlation was determined between the number of weed seedlings and oilseed rape yield and between the number of weed seedlings in the crop and plant population density of the spring oilseed rape crop either. 
The number and dry mass of weeds before oilseed rape harvesting in 2015. Pre-harvest assessment of weed counts in the spring oilseed rape crops sown at different dates suggested that in the crops sown on 15 and 20 April, the number of weeds was significantly on average 2.9 times higher compared with that in the crops sown at later dates (Fig. 2). The documented data have evidenced that from mid-May to mid-July is the period when weeds emerge most intensively (Špokiené, Povilionienè, 2003); however, in our study, emergence of weeds was not intensive in later sown crops, which resulted in lower weed counts before harvesting.

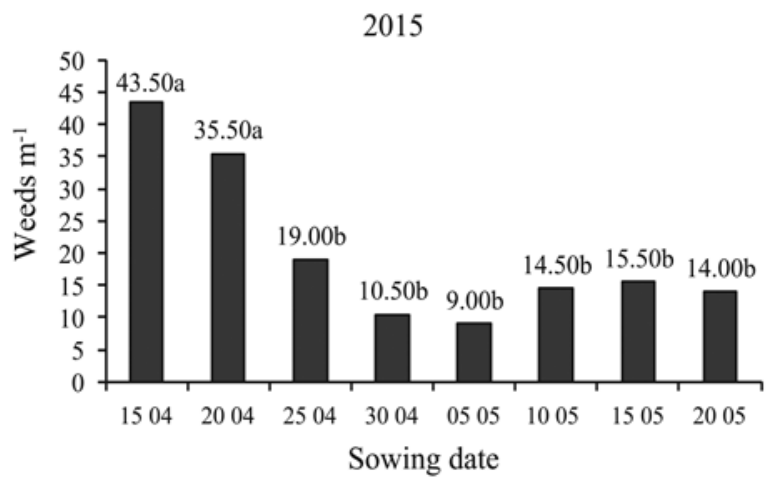

Explanation under Figure 1

Figure 2. The number of weeds in spring oilseed rape crop before harvesting, 2015

In the crops sown at later dates, 30 April and later, the dry mass of weeds tended to increase and had significant effect on rapeseed yield (Fig. 3). The crop sown at late dates, when the weather was much warmer, developed more rapidly but the crop plants were much smaller and therefore exhibited poorer suppression of weeds. Stougaard and Xue (2005) have reported that in denser crop stands weeds are more effectively smothered and this results in smaller yield losses caused by weed infestation. The highest dry mass of weeds before harvesting was recorded in the crops sown from 15 to 20 May, where it was by on average 5.9-fold higher compared with that in the crops sown at earlier dates. Very little dry mass of weeds was estimated in the crops sown at the earliest dates $(15,20$ and 25 April) compared with that in the crops sown at optimal dates (20 April to 10 May). The earlier the crop was sown and the denser the stand was formed, the higher the crop competitive power against weeds was. The weed incidence in the early sown $(15,20$ and 25 April) crops was low and the dry mass of weeds was significantly as many as 13.3 times lower compared with the crops sown at later dates (30 April, 5, 10, 15 and 20 May). The dry mass of weeds in the crops sown at late dates was 5.1-fold higher compared with that of the crops sown at optimal dates - from 20 April to 10 May.

The correlation-regression analysis revealed strong linear positive statistically significant correlation between the length of period from spring oilseed rape sowing to complete maturity and the number of weeds: $y=-110.438+1.136 \mathrm{x}(r=0.74, P<0.05)$. With the decreasing time from spring oilseed rape sowing to complete maturity the number of weeds before harvesting declined. Strong linear negative statistically significant correlation was established between dry mass of weeds and rapeseed yield: $y=1.742-0.005 x(r=-0.84$, $P<0.01)$. With increasing dry mass of weeds, rapeseed yield significantly decreased. The correlation-regression

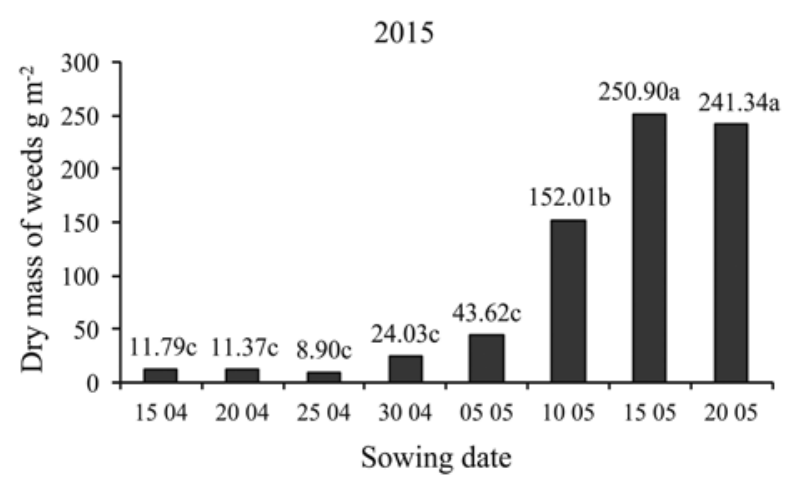

Explanation under Figure 1

Figure 3. The dry mass of weeds in spring oilseed rape crop before harvesting, 2015

analysis showed negative strong linear statistically significant relationship between the period of time from spring oilseed rape sowing to complete maturity and dry mass of weeds: $y=1420.385-11.543 x(r=-0.89$, $P<0.01)$. With the decreasing time from spring oilseed rape sowing to complete maturity the dry mass of weeds increased.

The number and dry mass of weeds before rapeseed harvesting in 2016. Pre-harvest assessment of weed incidence in spring oilseed rape crops revealed that sowing time had significant effect on the number of weeds. Although all oilseed rape crops were sprayed with herbicides after sowing, the number of weeds before harvesting was markedly higher than in spring after crop emergence and considerably differed among the experimental treatments. The crops sown at the earliest dates (10 and 15 April) successfully smothered weeds, whose number per unit area remained low and significantly lower, compared with that in the crops sown on 20 and 30 April and 5 May (Fig. 4). The crops sown on the latter dates had the highest number of weeds, which was significantly $68.0 \%$ higher compared with the crops sown on other dates. Beckie et al. (2008) have reported that when the conditions for oilseed rape emergence are very good, the crop plants can very well compete with weeds at initial growth stages; however, in our experiment the crop sown on 30 April emerged poorly, the stand was very thin and this favoured the spread of weeds. With a 30 to 45-day delay in sowing, the number of weeds significantly decreased in the spring oilseed rape crop before harvesting compared with that in the crops sown from 20 April to 5 May.

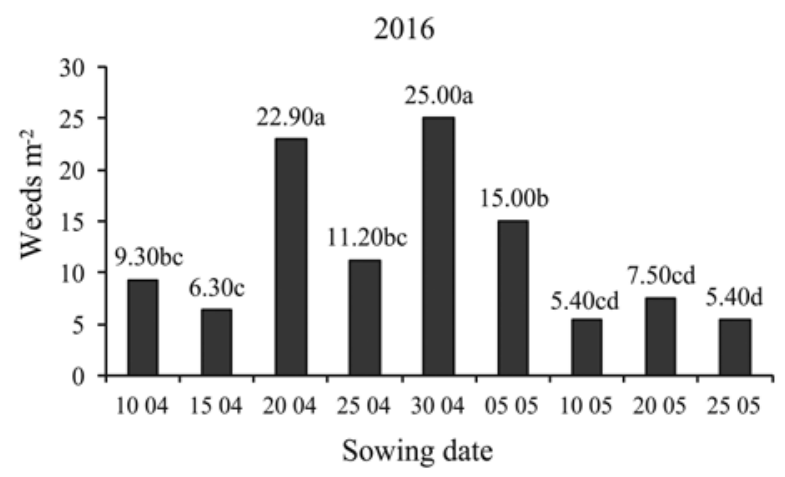

Explanation under Figure 1

Figure 4. The number of weeds in spring oilseed rape crop before harvesting, 2016 
The highest dry mass of weeds was recorded in the crops sown on 20, 25 and 30 April, where it ranged from 144.4 to $179.9 \mathrm{~g} \mathrm{~m}^{-2}$ (Fig. 5). Significantly the lowest dry mass of weeds $\left(1.5 \mathrm{~g} \mathrm{~m}^{-2}\right)$ was estimated in the crops sown on 15 April. In the crops sown at the latest dates (20 and 25 May), the dry mass of weeds was similar to that in the crops sown earlier (10 and 15 April). Preharvest assessment of dry mass of weeds in the spring oilseed rape crops indicated that there was no significant difference in this value between the crops sown at the earliest date (10 April) and those sown at the latest date (25 May).

\section{6}

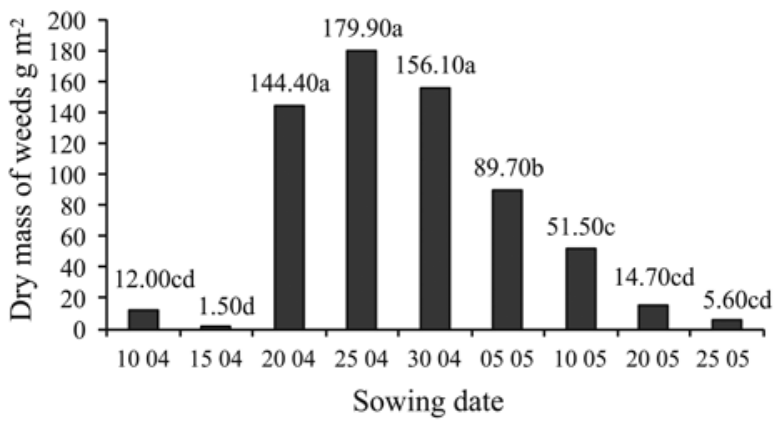

Explanation under Figure 1

Figure 5. Dry mass of weeds in spring oilseed rape crop before harvest, 2016

In 2016, there was found no statistically significant correlation between weed counts before harvesting and rapeseed yield.

\section{Conclusions}

1. In 2015, with a delay in spring oilseed sowing until 5 May, the number of weed seedlings decreased. The highest number of weed seedlings was recorded in the plots sown on 10 May, and later it declined. In 2016, in the crops of the earliest sowing dates (10 and 15 April), the number of weed seedlings was by $41.2 \%$ lower than in the plots sown at later dates. A 10-15 day delay in sowing resulted in significantly the highest number of emerged weeds, and in the plots sown at later dates the number of weeds inconsistently decreased.

2. In 2015, with a delay in spring oilseed rape sowing until 20 May, the number of weeds before harvesting had decreased by $67.8 \%$. The highest weed counts before harvesting were recorded in the spring oilseed rape plots sown at early dates (15 and 20 April). In the crops sown on 30 April and at later dates, the dry mass of weeds before harvesting had increased from 2.7 times to 27.1 times in the crop sown at the last sowing date and had significant effect on rapeseed yield. In 2016 , significantly the lowest number and dry mass of weeds were established in the crops sown at the earliest dates (10 and 15 April) and in those sown at the latest dates (10, 20 and 25 May). The highest weed counts were recorded in the crops sown on 20 and 30 April. The highest weed incidence in the spring oilseed rape crops sown on 30 April might have been caused by adverse weather conditions after sowing, which resulted in poor crop emergence.

3 . In 2015 , a statistically significant relationship was established between the dry matter mass of weeds and rapeseed yield $(r=-0.84, P<0.001)$. A statistically significant correlation was also determined between the length of period from oilseed rape sowing to complete maturity and dry matter mass of weeds $(r=-0.89, P<$ 0.01 ). In 2016 , no statistically significant correlations were found between the weed incidence in the spring oilseed rape crop and rapeseed yield.

\section{Acknowledgements}

This research was funded by a grant (No. SIT8/2015) from the Research Council of Lithuania.

Received 04102017 Accepted 11012018

\section{References}

1. Beckie H. J., Johnson E. N., Blackshow R. E., Gan Y. 2008. Weed suppression by canola and mustard cultivars. Weed Technology. 22: 182-185.

https://doi.org/10.1614/WT-07-126.1

2. Bilsborrow P. E., Evans E. J., Zhao F. J. 1993. The influence of spring nitrogen on yield, yield components and glucosinolate content of autumn-sown oilseed rape (Brassica namus). Journal of A gricultural Science. 120 (2): 219-224. https://doi.org/10.1017/S0021859600074268

3. Bullied W. J., Van Acker R. C., Marginet A. M., Kenkel N. C. 2006. Agronomic and environmental factors influence weed composition and canola competitiveness in southern Manitoba. Canadian Journal of Plant Science, 86 (2): 591-599. https://doi.org/10.4141/P05-042

4. Colbach N., Collard A., Guyot S. H., Mézière D., MunierJolain N. 2014. Assessing innovative sowing patterns for integrated weed management with a 3D crop: weed competition model. European Journal of Agronomy, 53: 74-89. https://doi.org/10.1016/j.eja.2013.09.019

5. Čiuberkis S., Karčauskienè D., Bernotas S. 2010. Climate variation and reduced soil tillage in Western Lithuania. Vagos, 88 (41): 14-21 (in Lithuanian).

6. Čiuberkis S., Vilkonis K. K. 2013. Weeds in Lithuanian agroecosystems: monograph. Akademija, Kedainiai distr., 256 p. (in Lithuanian).

7. Deytieux V., Nemecek T., Knuchel R. F., Gaillard G., Munier-Jolain, N. M. 2012. Is integrated weed management efficient for reducing environmental impacts of cropping systems? A case study based on life cycle assessment. Euronean Journal of Agronomv. 36 (1): 55-65. https://doi.org/10.1016/j.eja.2011.08.004

8. IPCC 2013. Summary for policymarkers. Climate change 2013: The physical science basics, 29 p. http://www.ipcc.ch/ pdf/assessment-report/ar5/wg1/WG1AR5_SPM_FINAL.pdf

9. Kažys J., Stankūnavičius G., Rimkus E., Bukantis A., Valiukas D. 2011. Long-range alternations of extreme high day and night temperatures in Lithuania. Baltica, 24 (2): 71-82.

10. Marcinkevičienè A., Velička R., Kosteckas R. 2010. Crop density and fertilization effects on weed suppression in spring oilseed rape. Zemdirbyste-Agriculture, 97 (2): 83-88.

11. Oerke E.-C. 2005. Crop losses to pests. The Journal of Agricultural Science, 144 (01): 31-43. https://doi.org/10.1017/S0021859605005708

12. Olesen J. E., Trnka M., Kersebaum K. C., Skjelvag A. O., Seguin B., Peltonen-Sainio P., Rossi F., Kozyra J., Micale F. 2011. Impacts and adaptation of European crop production systems to climate change. Euronean .Journal of Agronomy, 34 (2): 96-112. https://doi.org/10.1016/j.eja.2010.11.003

13. Parsons D. J., Benjamin L. R., Clarke J., Ginsburg D., Mayes A., Milne A. E., Wilkinson D. J. 2009. Weed Manager - a model-based decision support system for weed management in arable crops. Computers and Electronics in Agriculture. 65 (2): 155-167. https://doi.org/10.1016/j.compag.2008.08.007

14. Peltonen-Sainio P., Hakala K., Jauhiainen L., Ruosteenoja K. 2009. Comparing regional risks in producing turnip rape and oilseed rape - impacts of climate change and breeding. Acta Agriculturae Scandinavica, Section B: Soil and Plant Science. 59 (2): 129-138 https://doi.org/10.1080/09064710802022895 
15. Radzevičius G. 2011. Evaluation of the extreme climate change conditions impact to agricultural sector. Management Theory and Studies for Rural Business and Infrastructure Development, 4 (28): 99-109.

16. Raudonius S. 2017. Application of statistics in plant and crop research: important issues. Zemdirbyste-Agriculture. 104 (4): 377-382. https://doi.org/10.13080/z-a.2017.104.048

17. Reidsma P., Ewert F., Lansinkc A. O., Leemans R. 2010. Adaptation to climate change and climate variability in European agriculture: the importance of farm level responses. European Journal of Agronomy, 32 (1): 91-102. https://doi.org/10.1016/j.eja.2009.06.003

18. Renton M., Chauhan B. S. 2017. Modelling crop-weed competition: why, what, how and what lies ahead? Crop Protection. 95: 101-108. https://doi.org/10.1016/j.cropro.2016.09.003

19. Riemens M. M., Groeneveld R. M. W., Lotz L. A. P., Kropff M. J. 2007. Effects of three management strategies on the seedbank, emergence and the need for hand weeding in an organic arable cropping system. Weed Research, 47 (5): 442-451. https://doi.org/10.1111/j.1365-3180.2007.00582.x

20. Romaneckienè R., Pilipavičius V., Romaneckas K. 2008. Weed emergence and death in the crop of spring barley of different competitive ability. Žemès ūkio mokslai / Agricultural Sciences, 15 (1): 17-24 (in Lithuanian).

21. Seem J. E., Creamer N. G., Monks D. V. 2003. Critical weed-free period for 'Beauregard' sweet potato (Ipomoea batatas). Weed Technologv. 4 (17): 686-695.

https://doi.org/10.1614/WT02-089
22. Stougaard R. N., Xue Q. 2005. Quality versus quantity: spring wheat seed size and seedling rate effects on Avena fatua interference, economic returns and economic thresholds. Weed Research. 45 (5): 351-360. https://doi.org/10.1111/j.1365-3180.2005.00468.x

23. Stuogè I., Ribauskas V., Lazauskas S., Radzevičius G. 2012. Climate change impact on agriculture in Lithuania: challenges, situation analysis and forecast. Kaimo raidos kryptys žinių visuomeneje, 2 (4): 43-55 (in Lithuanian).

24. Špokienè N., Povilionienè E. 2003. Piktžolès: katalogas. Lithuanian University of Agriculture, 200 p. (in Lithuanian).

25. Valantin-Morison M., Meynard J. M. 2008. Diagnosis of limiting factors of organic oilseed rape yield. A survey of farmers' fields. Agronomy for Sustainable Development, 28 (4): 527-539. https://doi.org/10.1051/agro:2008026

26. Velička R., Mockevičienė R., Marcinkevičienė A., Pupalienė R., Butkevičienė L. M., Kriaučiūnienė Z., Kosteckas R., Čekanauskas S. 2015. The comparison of non-chemical weed control methods efficiency in spring oilseed rape crop under the conditions of organic farming system. Žemès ūkio mokslai / Agricultural Sciences, 22 (4): 189-197 (in Lithuanian).

27. WRB. 2014. World reference base for soil resources 2014. International soil classification system for naming soils and creating legends for soil maps. World Soil Resources Reports No. 106. FAO, Rome, p. 165-166.

ISSN 1392-3196 / e-ISSN 2335-8947

Zemdirbyste-Agriculture, vol. 105, No. 1 (2018), p. 21-26

DOI $10.13080 / \mathrm{z}-\mathrm{a} .2018 .105 .003$

\title{
Piktžolių plitimas skirtingu laiku pasėtų vasarinių rapsų pasẻliuose
}

\author{
R. Velička, R. Pupalienė, L. M. Butkevičienė, R. Kosteckas, Z. Kriaučiūnienė, S. Kosteckienė
}

Aleksandro Stulginskio universitetas

\section{Santrauka}

Klimato šiltejjimas ir anksčiau prasidedantis vegetacijos periodas leidžia paankstinti vasarinių žemės ūkio augalų sejją. Sėjos laikas gali turèti ịtakos piktžolių paplitimui žemès ūkio augalų, tarp jų ir vasarinių rapsų, pasẻliuose. Lauko eksperimentai buvo atlikti 2015 ir 2016 m. Aleksandro Stulginskio universiteto Bandymų stotyje. Eksperimento lauko dirvožemis - karbonatingas giliau glejjiškas išplautžemis (IDg4-k). Tyrimų tikslas - ịvertinti sèjos laiko įtaką piktžolių plitimui vasarinių rapsų pasėliuose. Vasarinių rapsų pirma sẻja buvo atlikta dirvai pasiekus fizinę brandą 2015 m. - balandžio 15 dieną, 2016 m. - balandžio 10 dieną, toliau sèjama kas 5 dienos, išskyrus 2016 m. 7-ą ir 8-ą sèją, tarp kurių 10 dienų laiko tarpas, susidaręs dèl nepalankių meteorologinių sąlygų. 2015 m. paskutinė sẻja buvo atlikta gegužès 20 dieną, 2016 m. - gegužěs 25 dieną. Piktžolių daigu skaičius ir piktžolių skaičius prieš derliaus nuėmimą atskirais eksperimento metais buvo nevienodas. $2015 \mathrm{~m}$., vasarinių rapsų sèją vèlinant iki gegužès 5 dienos, piktžolių daigų skaičius mažèjo. Piktžolių daigų daugiausia buvo rasta laukeliuose, kuriuose rapsai sèti gegužès 10 dieną, o sèją dar labiau vèlinant jų mažèjo. $2016 \mathrm{~m}$. sėją vẻlinant 10-15 dienų piktžolių daigų skaičius esmingai padidèjo, o sèjant dar vèliau - neesmingai sumažèjo. $2015 \mathrm{~m}$. vasarinių rapsų sèją vèlinant iki gegužès 20 dienos, piktžolių skaičius pasėlyje prieš derliaus nuėmimą esmingai sumažèjo (67,8 \%). Pasėliuose, sètuose balandžio 30 dieną ir vèliau, piktžolių sausųjų medžiagų masė prieš derliaus nuèmimą padidèjo nuo 2,7 iki 27,1 karto paskutinès sejjos pasėlyje ir turèjo esminès įtakos vasarinių rapsų sėklų derlingumui. $2016 \mathrm{~m}$. esmingai mažiausias piktžolių skaičius ir piktžolių sausujų medžiagų masė prieš derliaus nuėmimą nustatyta anksčiausiai (balandžio 10 ir 15 dienomis) ir vèliausiai (gegužès 10, 20 ir 25 dienomis) sètų vasarinių rapsų pasèliuose. 2015 m. nustatytas esminis koreliacinis priklausomumas tarp piktžolių sausujų medžiagų masès ir vasarinių rapsų sẻklų derlingumo $(r=-0,84, P<0,001)$. Esminis priklausomumas taip pat buvo nustatytas ir tarp laikotarpio (dienų) nuo vasarinių rapsų sejjos iki pilnosios brandos bei piktžolių sausujų medžiagų masès $(r=-0,89, P<0,01) .2016 \mathrm{~m}$. esminio priklausomumo tarp piktžolių paplitimo skirtingu laiku sėtų vasarinių rapsų pasėliuose ir vasarinių rapsų sėklų derlingumo nenustatyta.

Reikšminiai žodžiai: piktžolès, sėjos laikas, vasariniai rapsai. 